\title{
Effective Public-Private Partnership Models and their Application in Public Policy Implementation
}

Submitted 11/04/20, $1^{\text {st }}$ revision 10/05/20, $2^{\text {nd }}$ revision $23 / 06 / 20$, accepted $15 / 08 / 20$

\author{
Oksana V. Zakharina ${ }^{1}$, Volodymyr V. Korzhenko², Nataliia V. Kovalenko ${ }^{3}$, \\ Maryna V. Shashyna ${ }^{4}$, Antonina V. Tomashevska ${ }^{5}$, Iryna V. Mosiichuk ${ }^{6}$
}

\begin{abstract}
:
Purpose: The aim of the scientific article is to generalize the practice of using public-private partnership models and analyze the level of effectiveness of their application in the implementation of public policy.

Design/Methodology/Approach: Comparison, systematic and structural research, statistical and analytical, tabular, graphical, analytical modeling, as well as methods of abstraction and analysis are the research methods which were used in this article.

Findings: The study has found that to increase the effectiveness of public-private partnership models, the partnership should be built on the principles of agreement and coherence of interests of the parties. Existing infrastructure, combining different alternative sources of funding and possible long-term cooperation should be considered.

Practical Implications: This research raises awareness of the most effective models of cooperation between the state and the private sector are concession agreements, management contracts, leasing agreements and "greenfield projects". The effectiveness of these models of public-private partnership is associated with the diversification of risks between partners, including financial ones. It is about the ability to attract investment resources from various sources and the delegation of management and regulatory functions of the state to the private sector.

Originality/Value: The study highlights that the relative importance of the models of public-private partnership is context specific.
\end{abstract}

Keywords: Public-private partnership, state policy, forms and methods of state regulation, models of public-private partnership, monitoring of public-private partnership projects, agreements.

JEL Classification: M00, M21, M38, L32.

Paper type: Research article.

\footnotetext{
${ }^{1}$ Associate Professor, Zhytomyr National Agroecological University, Zhytomyr, Ukraine,

E-mail: ovzakharina@ukr.net;

${ }^{2}$ Professor, O.M. Beketov Kharkiv National University of Urban Economy, Kharkiv, Ukraine,

E-mail: KorgenkoVV@gmail.com;

${ }^{3}$ Associate Professor, Kharkiv Regional Institute of Public Administration of the National Academy of Public Administration under the President of Ukraine, Kharkiv, Ukraine, E-mail: nkovalenko2008@ukr.net;

${ }^{4}$ Associate Professor, National Technical University of Ukraine "Igor Sikorsky Kyiv Polytechnic Institute", Kyiv, Ukraine, E-mail: Shashyna.marina@gmail.com;

${ }^{5}$ Associate Professor, V. Stefanyk Precarpathian National University, Ivano-Frankivsk, Ukraine,

E-mail: lianeta2013@gmail.com;

${ }^{6}$ Senior Lecturer, Zhytomyr Ivan Franko State University, Zhytomyr, Ukraine, E-mail: mosiychuk_i@ukr.net;
} 


\section{Introduction}

The modern stage of development of social and economic processes of public-private partnership is a highly effective mechanism for organizing cooperation between two key actors in the economic system: the private sector, and the state. The multi-vector and complex structure of such cooperation requires the usage of proven methods that are adapted to the modern business environment of implementation of promising projects. The success of these projects directly depends on the choice of public-private partnership models and approaches to partnership agreements.

The usage of effective public-private partnership models is an effective alternative to traditional methods of managing strategically important sectors of the economy. Therefore, a comprehensive study of these issues aims to identify real opportunities for economic development at the national and interstate levels.

Today the main obstacles to the development of public-private relations are the lack of effective methods that allows increasing the effectiveness of public policy in the active usage of public-private partnership, as well as weak institutional and information support for cooperation between government and business. Improving the quality of such a partnership is possible by providing the formation of a well-thought-out theoretical and methodological basis for public-private partnership, effective usage of the country's competitive potential and consideration the successful experience of the world.

\section{Literature Review}

A serious study of the issue outlined in the scientific article allows us to conclude that the topic of practical application of effective and rational models of public-private partnership in the public policy implementation today is sufficiently studied by Ukrainian and foreign scholars and relevant for detailed study. The history of public-private partnership development as a separate area of cooperation between the state and business and the development of public-private partnership models begins with the formation of conceptual provisions of the theory of state regulation of the economy. Modern researchers as Osei-Kyei and Chan (2015) supported this point of view and believed that such a mechanism of the state and business was the most effective in the practical implementation of public policy.

Considering the essence of public-private partnership processes and existing models of such cooperation, USAID proposed to consider public-private partnership as a "new tool of economic development". Such interpretation of scholars emphasizes the importance of the public-private partnership mechanism as a method of influencing the economic sphere (International Budget Partnership, 2018).

The peculiarities of public-private partnership models and their practical application are reflected in the recommendation acts of the European Union. So, according to the Green Paper on Public-Private Partnerships and Local Legislation on Public Contracts and Concessions (European Commission, 2004), the public-private partnership model is seen as a special form of public-private partnership aimed at implementing certain tasks or providing services. It also provides financing, construction, or operation of infrastructure projects.

Researchers and analysts of leading consulting companies have dealt with the problems of determining the effectiveness of public-private partnership models. The representatives of Price Waterhouse Coopers (2005) say that public-private partnership models should be an agreement between the public and private sectors. The drawing up of such agreement is associated with the achievement of common goals. The analysts of KPMG (KPMG Business Academy, 2015) emphasize the importance of mutually agreed cooperation of the parties. It is especially important because the models of public-private partnership in their understanding are a special kind of cooperation in the direction of joint investment projects.

The main advantages of the application of public-private partnership models in the practical implementation of public policy have been studied in the works of Verhoest et al. (2015). These researchers claim that the positive consequences of cooperation between the state and business are the 
usage of experience in the implementation of strategically important projects by public authorities. The practical implementation of such projects is mainly carried out by private sector entities. Sharing such experience reduces the cost of implementing priority projects and increases their quality and effectiveness.

The importance of regulatory functions of the state in social and economic and household processes was emphasized in the work of Holovatyi (2015). The scientist claims that the main goal of the state, including in the processes of public-private partnership is the consolidation of modern society. Rationally selected mechanisms for implementing public policy and applying effective tools to influence the private sector are a prerequisite for meeting the needs of citizens and a method of protecting the interests of consumers and the private sector. However, modern society is characterized by the problem of intensifying the destructive function of the state, as it penetrates into all spheres of management and destroys the structure of the national economy in the face of the executive power (Holovatyi, 2015).

The World Bank proposed a classification where we can see one well-studied approach that characterizes public-private partnership models. It has been widely used in cooperation between the state and the private sector around the world (World Bank, 2020). There are four models of effective partnership models according to it: management and lease contracts; concessions; agreements such as "Rehabilitate - operate - transfer" (ROT), "Build - rehabilitate - operate - transfer" (BROT), "Rehabilitate - lease or rental - transfer" (RLT); projects that include "key ready" building (Greenfield projects); agreements such as "Build - lease - transfer" (BLT), "Build - operate - transfer" (BOT), "Build - own - operate" (BOO), commercial projects (Merchant), rent (Rental); sale of assets (divestiture) (World Bank, 2020). According to Davies and Fairbrother (2003), there are five most effective models of public-private partnership: Greenfield projects; divestiture; concessions; management and outsourcing contracts; leasing. Ukrainian legislation stipulates that the most effective models of partnership between the state and business are the conclusion of concession agreements concerning state and municipal property; property management with a mandatory condition of investment obligations of a private partner; publicprivate partnership model on the basis of the agreement on joint activity (Kruglov, 2018).

The data of the European PPP Expertise Center (2020a; 2020b) (hereinafter - EPEC) were analyzed in order to study the dynamics of the most effective models of public-private partnership. They show the success of more than 1,800 projects (as of 2019) that were implemented in 26 countries.

\section{Materials and Methods of Research}

Methods of comparison, abstraction and analysis were used to process statistical and analytical data, as well as the main indicators of public-private partnership development, which made it possible to distinguish various economic concepts, identify their characteristics and principles of action on public policy. Systematical and structural research was used to outline the conceptual basis for the usage of public-private partnership models. Statistical and analytical, method has been widely used in the analysis of the dynamics of the application of public-private partnership models in the international and domestic practice. At the same time, due to the usage of tabular, graphical, and analytical modeling, the analysis of cost and quantitative indicators of infrastructure and innovation projects is also used. It was done by applying effective public-private partnership models in terms of individual countries and different sectors of the economy.

\section{Research Results}

The results of the analysis of basic theories of partnership development between the state and private sector, as well as the practice of applying effective public-private partnership models indicate the necessity to maintain a rational balance of power and responsibility between government and business sector. The harmonious combination of interests, powers, and capabilities of both parties of publicprivate partnership - public and private (market) sectors - ensures the effectiveness of the main 
infrastructure projects, the development of national economies of certain countries and the global crises overcoming.

The high efficiency of the public-private partnership models and their application in the process of implementation of the state policy and social and economic development is connected with the following features that characterize the effectiveness of cooperation between the state and the private sector:

- first, the result of applying a specific model of public-private partnership depends on the level of provision of public infrastructure or public services through the private sector. The essence of this feature is the redistribution of risks that arise in the preparation and implementation of strategically important projects. In addition, the level of financial reward of private businesses is determined depending on the riskiness of the chosen model of partnership (Sharma and Bindal, 2014);

- secondly, an effective public-private partnership model is based on a combination of different project financing methods: partly at the expense of the private sector and partly through the state budget, but it is possible to use schemes involving additional parties;

- thirdly, the period of cooperation between the state and private business in the application of public-private partnership models is quite long, as effective cooperation must include several stages of infrastructure projects - design, construction, operation and / or maintenance of fixed assets in combination with private financing (Yashchenko, 2018).

The effectiveness of the public-private partnership model in the practical implementation of strategically important projects depends on the level of risk balance between the private and public sectors and the degree of private partner involvement. Characteristics of modern public-private partnership models are shown in Figure 1.

Figure 1. Models of the public-private partnership model depending on the level of risk sharing between partners and the level of private partner involvement

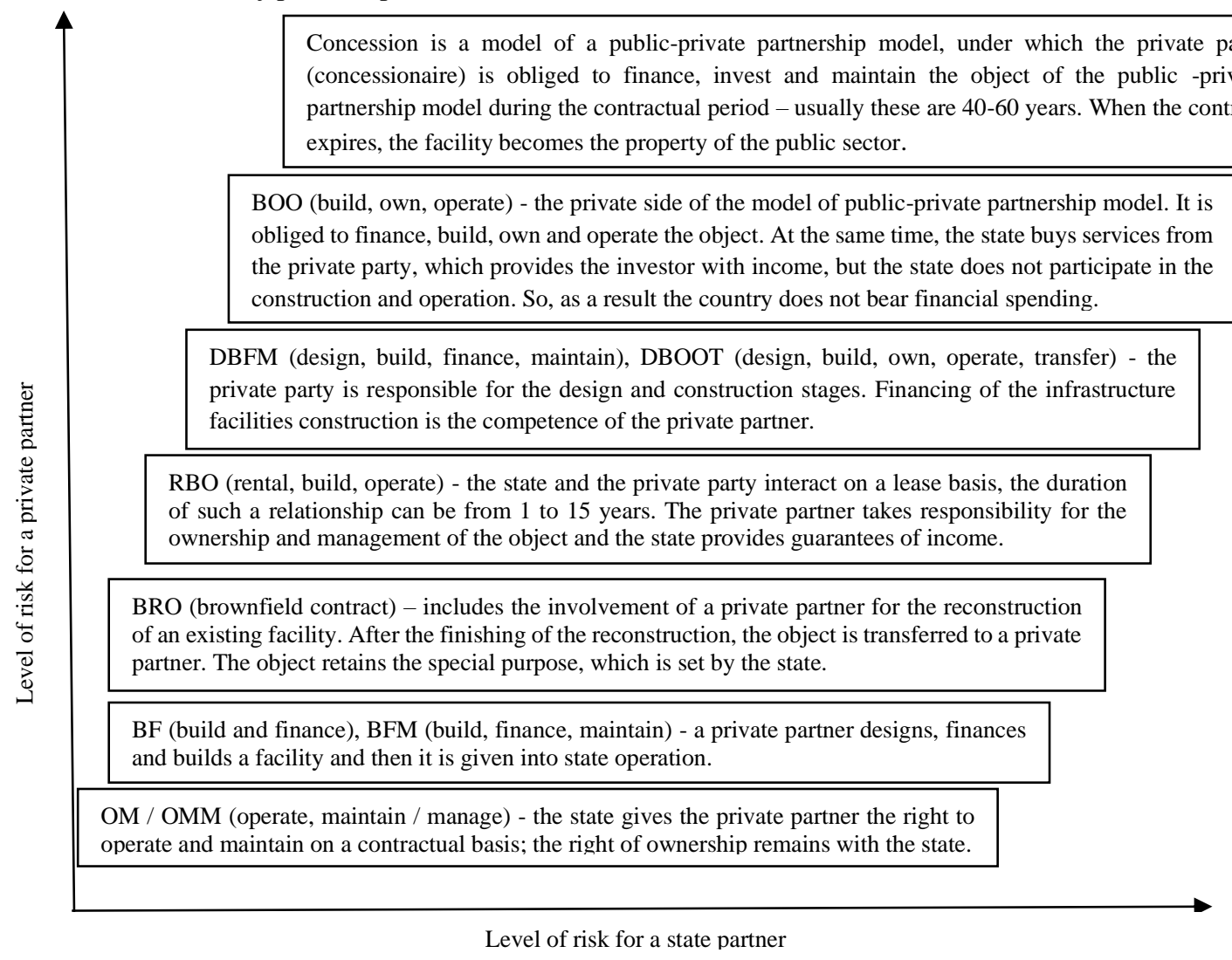

Source: (Canadian Council for Public-Private Partnerships, 2011; Roehrich et al., 2013; Yashchenko, 2018) 
A positive trend of the partnership for both the public and private sectors is the increase in the level of staff's productivity by creating favorable conditions for self-development. The active application of scientific, technical, and innovative developments in the activities of economic entities encourages employees to improve their professional knowledge and skills. Taking this into account, the share of able-bodied population that has information about modern scientific, technical, and innovative developments and knows how to use them in practice, is growing steadily (Khytrova et al., 2020). In turn, the competence of personnel, the professional level of specialists and the accuracy of the assessment of information data significantly affect management decisions that determine the effectiveness of the business entity and the efficiency of the selected model of partnership between the state and the private sector (Haiduchok et al., 2020).

To determine the most effective models of cooperation between the state and the private sector, it is advisable to analyze successful world experience of such projects. The United Kingdom, France and Germany are the leaders in the application of public-private partnership models in the practical implementation of innovation and infrastructure development projects (Table 1).

Table 1. Some features and the application of effective models of public-private partnership in certain countries

\begin{tabular}{|c|c|c|}
\hline Country & $\begin{array}{l}\text { Working models of public- } \\
\text { private partnership in a proper } \\
\text { country (according to the World } \\
\text { Bank classification) }\end{array}$ & Importance in the implementation of public policies \\
\hline 总 & $\begin{array}{l}\text { 1. Concession agreements; } \\
\text { 2. Management contracts; } \\
\text { 3. Greenfield projects. }\end{array}$ & $\begin{array}{l}\text { Can be implemented in different spheres: transport, health, } \\
\text { education, housing and municipal services, waste management, } \\
\text { defense, information technology and residential construction in } \\
\text { order to ensure the strategic goals of social and economic } \\
\text { development of the national economy. }\end{array}$ \\
\hline 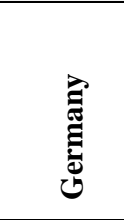 & $\begin{array}{l}\text { 1. Concession agreements; } \\
\text { 2. Leasing; } \\
\text { 3. Management contracts; } \\
\text { 4. DBFM agreements (design, } \\
\text { build, finance, maintain) and BOT } \\
\text { (build, operate, transfer). }\end{array}$ & $\begin{array}{l}\text { Can be implemented in different spheres: transport, utilities, energy, } \\
\text { health and education in order to ensure sustainable development of } \\
\text { the transport system, improve the quality of housing services and } \\
\text { create an effective system of medical services }\end{array}$ \\
\hline 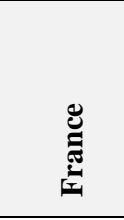 & $\begin{array}{l}\text { 1. Concession agreements; } \\
\text { 2. Management contracts; } \\
\text { 3. Greenfield projects. }\end{array}$ & $\begin{array}{l}\text { Can be implemented in different spheres: transport, health, } \\
\text { education, housing, waste management and residential construction } \\
\text { in order to create conditions for the powerful development of } \\
\text { construction process and improve the mechanism of functioning of } \\
\text { public utilities. An important area of work in the context of public } \\
\text { policy is the creation of an extensive system of parking zones. }\end{array}$ \\
\hline
\end{tabular}

Source: Compiled by the authors according to the data EPEC (2020a), Fadiushyn (2019).

So, the most effective model of public-private partnership in the UK is cooperation based on concession agreements. Private financial initiative is fixed under a conditional contract for the provision of services that are financed by private parties through their own investments. The effectiveness of this model is connected to the application of penalties for non-compliance.

The German government prefers public-private partnership models that establish the ultimate ownership of the state. Such models are effective within the country because they consider the principle of the federal mechanism and the associated features of the financial independence of the federation. Within partnership models, the private party receives temporary rights to maintain infrastructure in good condition. So, the private partner has only the right to operate and is committed to provide quality services to the people in this country.

The practice of France shows the spread of public-private partnership models with the usage of concession agreements. The partnership between the state and the private sector is regulated by the Societe d'Economie Mixtes (SEM), the main goal of which is to increase the effectiveness of publicprivate partnerships in conditions of fierce competition. SEM creates an appropriate business 
environment for the application of effective public-private partnership models, which has a significant positive impact on public policy (Pidhaiets, 2011).

The total cost of projects implemented by leading European countries in 2019 and their number is shown in Figure 2.

Figure 2. Indicators of the total cost and number of public-private partnership projects implemented by leading European countries in 2019 (billion euros)

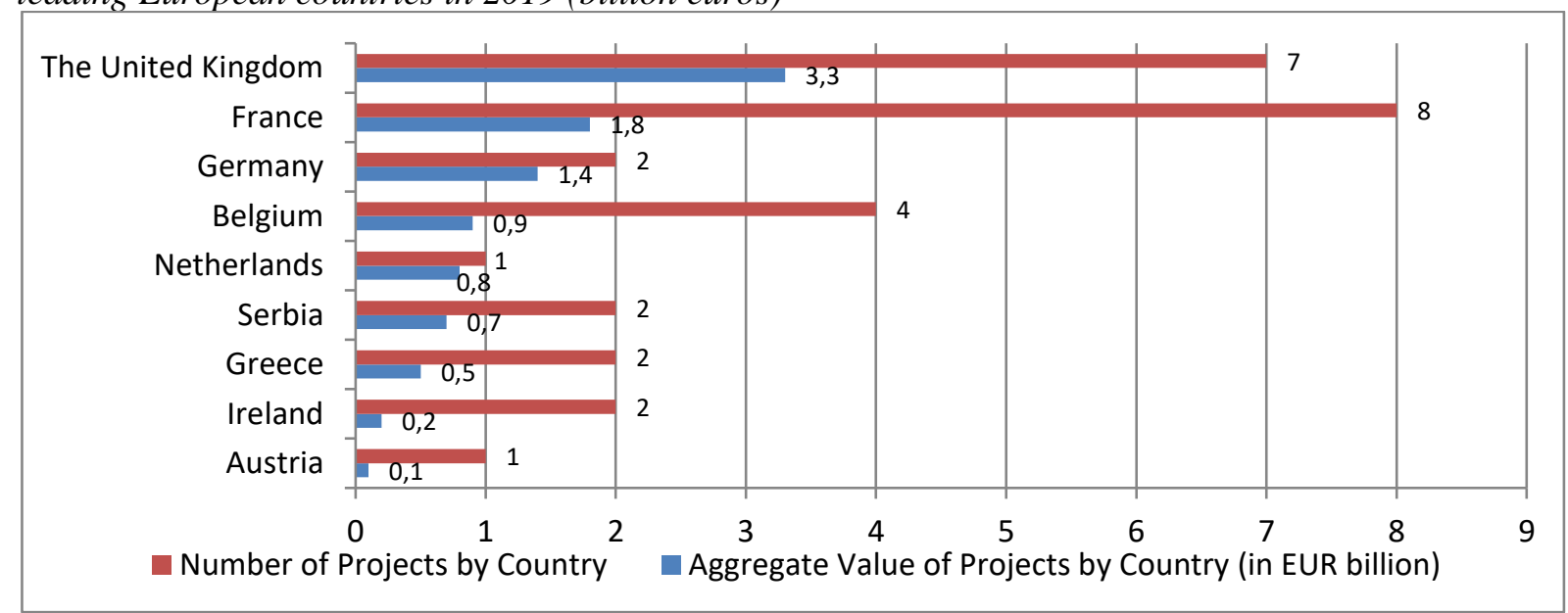

Source: Compiled by the authors according to the data EPEC (2020b).

The usage of public-private partnership models is typical for the implementation of public policy in transport, housing, education, telecommunications, environmental, public, defense, cultural and other spheres of life in different European countries. The amount of expenses for financing promising publicprivate partnership projects and the number of projects implemented in 2019 in the European market in terms of different industries is shown in Figure 3.

Figure 3. Indicators of total expenses and the number of public-private partnership projects by industry in 2019 (billion euros)

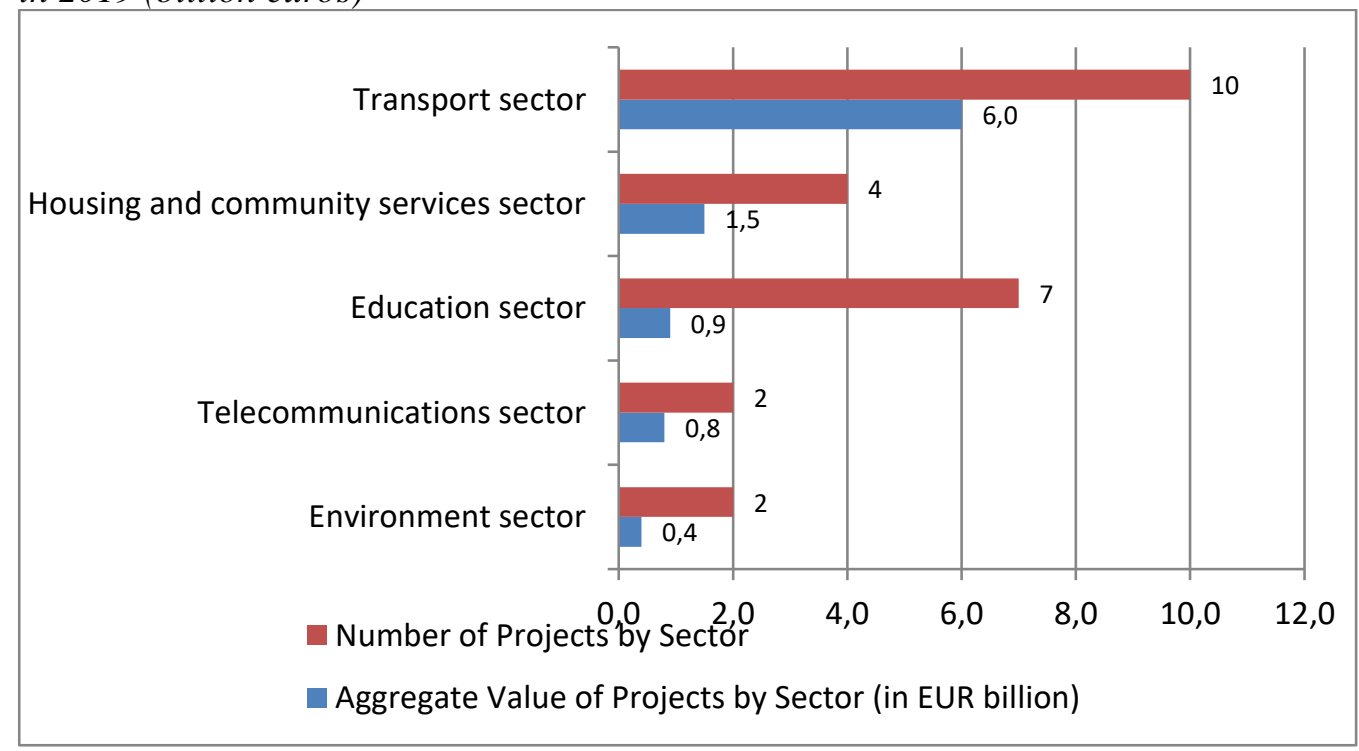

Source: Compiled by the authors according to the data (EPEC, 2020b).

The ten-year dynamics of the total cost of projects implemented in the European market through the mechanism of public-private partnership is shown in Figure 4. 
Figure 4. Dynamics of the total cost of public-private partnership projects during 2010-2019 (billion euros)

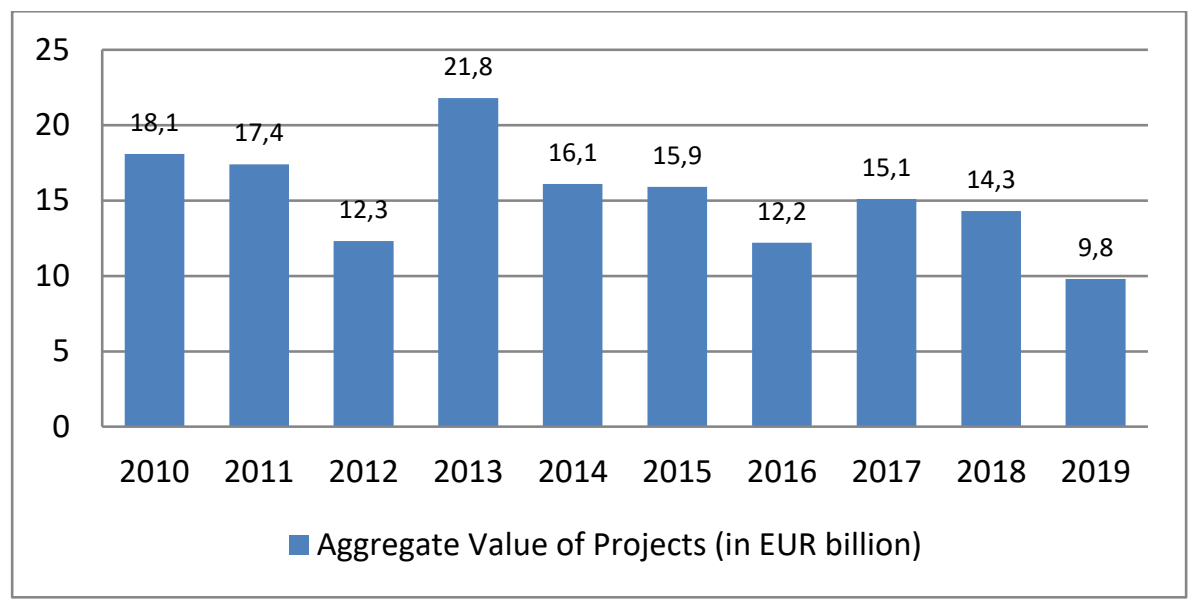

Source: Compiled by the authors according to the data EPEC (2020b).

So, in 2019, the total cost of public-private partnership projects, which were implemented in European countries and which were closed in 2019, amounted to 9.8 billion euros, which is $31 \%$ less than in 2018 ( 14.3 billion euros). In turn, the number of public-private partnership projects that were implemented in 2019 and closed was 29. It should be noted that the number of public-private partnership projects in 2019 is the lowest since 1996 (EPEC, 2020b).

The practice of applying public-private partnership models in Ukraine is just beginning to develop and therefore the effectiveness of strategically important infrastructure and innovation projects through public-private partnerships is much lower than in leading countries in Europe and the world. According to the central and local executive bodies, on the first of January 2020, there were concluded 187 agreements within the implementation of state policy based on public-private partnership: 52 agreements are relevant and are being implemented. Among them 34 concession agreements, 16 agreements about joint activities and 2 other agreements, 135 agreements are not implemented. Among them 4 contracts were closed, 1 project was implemented, 18 contracts were terminated, and 113 contracts were not fulfilled for various reasons (Figure 5).

Figure 5. The condition of public-private partnership in Ukraine

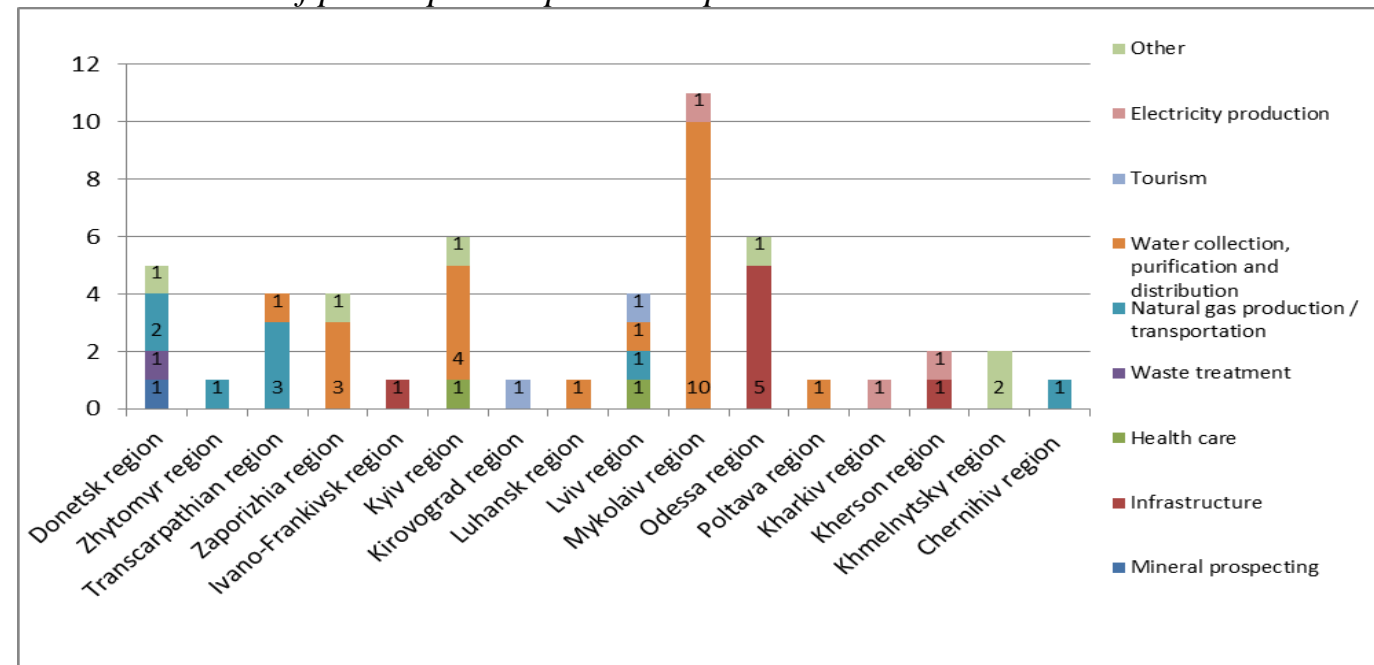

Source: Compiled by the authors according to the data Ministry for Development of Economy, Trade and Agriculture of Ukraine (2020). 
So, the effectiveness of public-private partnership models depends on the level of motivation of both the private partner and the state, but in the process of establishing cooperation, the common interests of the parties should remain priority aspects infrastructure development, increasing social and economic development, payback and profits from project implementation, reducing unemployment and increasing local budget revenues, which is especially important in the context of decentralization and social cohesion policy.

\section{Discussion and Conclusions}

The study has found that the effectiveness of public-private partnerships is related to several factors. First, the rational distribution of risks, obligations and responsibilities between the parties of the agreement; secondly, the expansion of project financing, including at the expense of credit funds, the return of which is guaranteed by state and local authorities; third, the legality and right basis of such relations.

The further development of public-private partnerships should be built in accordance with the successful experience of certain countries, the leaders of which are the United Kingdom, France, and Germany. The development of public-private partnership in these countries is carried out based on a perfect legal and institutional basis, and the quality of project results is ensured by the coherence of the interests of the parties.

Effective ways of solving existing problems should be considered to increase the efficiency and effectiveness of public-private partnership models. Among them are the following:

- improving the conditions of private sector management, which intensifies business processes and becomes a driving factor in the implementation of public-private partnership models in the institutional structure of the country;

- considering the state policy of decentralization in the processes of partnership between the government and the private sector, which is caused by different economic and social efficiency of projects at the national and local levels.

Here it is said about strategic projects that are implemented in the transport and energy industries. They are especially useful at the national level, but projects for the development of social and housing spheres are more effective within regional and local policies achieving a balance of commercial and social efficiency of public-private partnership models.

\section{References:}

Canadian Council for Public-Private Partnerships. 2011. Public-Private Partnerships: a Guide for Municipalities. Available at: http://nadimiran.ir/wp-content/uploads/2014/08/PDF.

Davies, S., Fairbrother P. 2003. Private Finance Initiative (PFI) and Public Private Partnerships (PPPs): Definitions and Sources. Working Paper Series, Paper 39. Available at: https://www.academia.edu/27945919/Private_Finance_Initiative_PFI_and_Public_Private_Partnerships_ PPPs_Definitions_and_Sources.

European Commission. 2004. Green Paper: On public-private partnerships and Community law on public contracts and concessions. Available at: https://op.europa.eu/en/publication-detail/-/publication/94a3f02fab6a-47ed-b6b2-7de60830625e/language-en.

European PPP Expertise Center. 2020a. Market Update: Review of the European PPP Market in 2019. Available at: https://www.eib.org/attachments/epec/epec_market_update_2019_en.pdf.

European PPP Expertise Center. 2020b. Public-private partnerships financed by the European Investment Bank from 1990 to 2019. Available at: https://www.eib.org/attachments/epec/epec_ppp_financed_by_eib_1990_2019_en.pdf.

Fadiushyn, I.S. 2019. International experience of PPP development. International Research Journal, 4(82), 39-43. 
Haiduchok, T., Sysoieva, I., Vasylishyn, S., Lysiuk, A., Kundrya-Vysotska, O., Kostyrko, A. 2020. Accounting and control of settlements with counterparties under the conditions of quarantine measures. International Journal of Advanced Research in Engineering and Technology, 11(5), 141-152.

Holovatyi, M. 2015. The state and society: The conceptual foundations and social interaction in the context of formation and functioning of states. Economic Annals-XXI, 9-10, 4-8.

International Budget Partnership. 2018. Open Budget Survey 2017. Available at: https://www.internationalbudget.org/publications/open-budget-survey-2017/.

Khytrova, O.A., Sysoieva, I.M., Dolha, H.V., Peniuk, V.O., Motuzenko, O.V. 2020. Ensuring the growth of enterprises and organizations through the motivation of managerial staff. International Journal of Economics and Business Administration, 8(2), 219-228.

KPMG Business Academy. 2015. Public-Private Partnerships (PPP): Emerging global trends and the implications for future infrastructure development in Australia. Available at: https://assets.kpmg/content/dam/kpmg/pdf/2015/06/public-private-partnerships-june-2015.pdf.

Kruglov, V.V. 2018. Models of Public-Private Partnership. Derzhava ta rehiony. Seriya: Derzhavne upravlinnya, 2(62), 56-61.

Ministry for Development of Economy, Trade and Agriculture of Ukraine. 2020. Status of PPP implementation in Ukraine. Available at: https://www.me.gov.ua/?lang=en-GB.

Osei-Kyei, R., Chan, A.P.C. 2015. Review of studies on the critical success factors for Public-Private Partnership (PPP) projects from 1990 to 2013. International Journal of Project Management, 33(6), 1335-1346. https://doi.org/10.1016/j.ijproman.2015.02.008.

Pidhaiets, S. 2011. European experience of application of Public-Private Partnership models. Zhurnal Yevropeiskoi Ekonomiky, 3(10), 291-305.

Price Waterhouse Coopers. 2005. Delivering the PPP promise. A review of PPP issues and activity. Price Waterhouse Coopers, London, UK.

Roehrich, J.K., Barlow J., Wright S. 2013. Delivering European health care through public-private partnerships: The theory and practice of contracting and bundling. In: T.K. Das (Ed.), Managing Public-Private Strategic Alliances. Information Age Publishing New York, NY, 1-42.

Sharma, M., Bindal, A. 2014. Public-Private Partnership. International Journal of Research (IJR), 1(7), 12701274.

Verhoest, K., Petersen, O.H., Scherrer, W., Soecipto, R.M. 2015. How do governments support the development of Public Private Partnerships? Measuring and comparing PPP Governmental Support in 20 European countries. Transport Reviews, 35(2), 118-139. https://doi.org/10.1080/01441647.2014.993746.

Yashchenko, N.L. 2018. A definition and features of public-private partnership. Pravova derzhava, 32, 119-128. https://doi.org/10.18524/2411-2054.2018.32.149577.

World Bank. 2020. Private Participation in Infrastructure Database. Available at: https://ppi.worldbank.org/en/ppidata. 